\title{
Entering the Bedroom through the Judicial Archives: Sexual Intimacy in Eighteenth-Century Toulouse
}

\author{
Mathieu Laflamme
}

In May 1768, Jeanne Ligonès filed a plainte en grossesse to the municipal court of Toulouse. ${ }^{1}$ Despite many displays of affections and promises of faithfulness, her lover, sieur Couly, had abandoned Jeanne, who was nearly four months pregnant and therefore could no longer hide the fruit of their relationship. A plainte en grossesse initiated a legal procedure during which an unmarried woman, in compliance with the Royal Edict of 1556, reported her illegitimate pregnancy to a competent judicial authority and thereby took legal steps towards financial compensation for damages. ${ }^{2}$ Jeanne stated to the capitouls town councillors and judges in civil and criminal matters - that Couly had seduced her and that their relationship was harmonious, loving, and, more importantly, consensual. ${ }^{3}$ On Jeanne's recommendation, a young caffetier was called as a witness: preparing coffee in his clients' homes, ${ }^{4}$ he was privy to their intimate lives. In front of the magistrates, the young man claimed that:

Dans le careme dernier il a été pendant un mois ou environ journellement vers les huit a neuf heures du matin partir du caffé au lait et des

* This paper is based on research carried out within the framework of my $\mathrm{PhD}$ fellowship at the University of Ottawa and the University of Toulouse, supervised by Sylvie Perrier (Ottawa) and Sylvie Mouysset (Framespa, UT2J). All translations are mine, unless otherwise stated.

1 A plainte en grossesse is a judicial deposition initiated voluntarily - or under family pressure - by unmarried pregnant women or widows whose goal it is to prosecute the alleged perpetrator of their pregnancy and thereby obtain financial compensation for their illegitimate pregnancy. In some instances, this also involves a plead of having the unwanted child admitted to the hospital, that is, the forerunner of orphanages. In the absence of an equivalent term in English and to avoid any loss of meaning, I maintain the term in French.

2 Phan M.-C., Les amours illégitimes. Histoires de séduction en Languedoc (1676-1789) (Paris: 1986).

3 Toulouse Municipal Archives (hereafter: АMT), FF812/4 liasse 95.

4 Both Jeanne and sieur Couly were members of the French provincial petite bourgeoisie (petty bourgeoisie) and therefore had the financial means to consume coffee, a luxury product in eighteenth-century Toulouse. 
bavaroyses a la plaignante et au sieur Couly [...] et qu'il a souvent trouvé ledit Couly et la plaignante couchés ensemble qu'il leur servoit le caffé au lit quand il les y trouvoit et que la plaignante prenoit ordinerement des

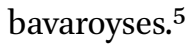

During Lent last year and for about a month, he would each day, between eight and nine in the morning, prepare coffee with milk and bavaroises for the plaintiff and for sieur Couly [...] and that he often found the said Couly and the plaintiff sleeping together: he served them coffee in bed when he found them there; it was normally the plaintiff who ordered bavaroises.

Invited into the private and intimate space of these two suitors, the caffetier was able to give evidence as to the sexual intimacy of an illegitimate couple. This fascinating testimony is not unique, however. Establishing the history of sexual behaviour was an important part of the juridical process. Judges had to establish the nature of the relationship before they could determine whether a sentence should be imposed on the defendant. In doing so, it was essential for both parties to describe the relationship in great detail and thereby reveal the nature of their sexual intimacy. Thus, the plaintes en grossesse allows historians unique access to the representations or discourses of the sexual, emotional, and affective intimacy of couples living out their sexuality on the margins of legality in eighteenth-century France.

Legal sources have often been used to study the repression of sexual behaviours. Inspired by Foucault's conceptions of sexuality, historians of the early modern period have focused on the 'tools' and 'techniques' of repression - that is, the criminalisation of sexual behaviours. ${ }^{6}$ Still, the early modern history of intimacy, at least when it comes to what we might call ordinary people, remains relatively understudied. ${ }^{7}$ A study of plaintes en grossesse can partially address this lack of research. ${ }^{8}$ With this chapter, I thus provide a methodological and conceptual approach for the study of sexual intimacy through judicial

5 АMT, FF812/4 liasse 95 .

6 Foucault M., Histoire de la sexualité. La volonté de savoir (Paris: 1984).

7 As a result, the intimacy of the socio-economic elite has attracted much more attention, see, e.g., Holloway S., The Game of Love in Georgian England: Courtship, Emotions, and Material Culture (Oxford: 2019); Lipscomb S., The Voices of Nimes: Women, Sex, and Marriage in Reformation Languedoc (Oxford: 2019).

8 For an excellent study of the sexuality of ordinary people in early modern France, see Hardwick J., Sex in an Old Regime City: Young Workers and Intimacy in France, 1660-1789 (Oxford: 2020). 
archives. More specifically, I shall analyse the plaintes en grossesse as a kind of écrit du for privé or egodocument, ${ }^{9}$ which opens a rare window into the everyday life of past individuals and, more importantly, into their shared sphere of intimacy. ${ }^{10}$

The Dutch historian Jacques Presser defined egodocuments in the 196os 'as those historical sources in which the researcher is faced with an "I" or occasionally a "he" as the writing and describing subject has a continuous presence in the text $[\ldots]$ or those documents in which an ego deliberately or accidentally discloses or hides itself'.11 He specifies that this ego can be deliberately

$9 \quad$ "Écrits du for privé" can be defined as non-fictional texts produced by ordinary people. In general, such texts were produced outside an institutional framework and thereby constitute personal statements about the self, his/her family, and community, see Arnoul E. - Renard-Foultier R. - Ruggiu F.-J., "Les écrits du for privé en France de la fin du Moyen Âge à 1914: bilan d'une enquête scientifique en cours. Résultats de 2008-2010", in Henryot F. (ed.), L'historien face au manuscrit. Du parchemin à la bibliothèque numérique (Louvain-la-Neuve: 2012) 167-188. Danièle Tosato-Rigo argues that the terminological definitions of personal writing must be adapted to each socio-historical context and that research suffers from those language barriers, see Tosato-Rigo D., "Introduction", Études de Lettres 1-2 (2016) 9-11. While my research is focused on French sources, I nevertheless use the term 'ego-document' because it unites many different approaches to personal writings. See also Green's contribution to this volume.

10 It was not until the 1970s that French historians engaged with documents that testify to this mode of personal writing. In 1985, Madeleine Foisil classified these documents as the 'écrits du for privé', cf. Foisil M., "L'écriture du for privé", in Aries P. - Duby G. - Chartier R. (eds.), Histoire de la vie privée, vol. 3 (Paris: 1985) 319-357. Since then, a rich field of research has developed, which targets such sources and their precious testimonies of intimate lives and private states. This historiographic development is characterised by the return of the individual in history and a profound renewal of social history. For an overview of the field, see Ruggiu F.-J., "Les écrits du for privé: une perspective européenne", in Bardet J.-P. Arnoul E. - Ruggiu F.-J. (eds.), Les écrits du for privé en Europe du Moyen Age à l'époque contemporaine (Bordeaux: 2010) 9-18 and Greyerz K., "Egodocuments. The Last Word?", German History 28 (2010) 263-272. In turn, Sylvie Mouysset and François-Joseph Ruggiu have argued for an expansion of what constitutes 'écrits du for privé.' Including sources on the margin of Foisil's classification, they propose to study urban chronicles, family correspondences, and ambassadorial relations as personal writings, Mouysset S. - Ruggiu F.-J., "À la recherche du soi dans écrits du for privé", in Mouysset S. - Ruggiu F.-J. - Bardet J.-P. (eds.), Car c'est moy que je peins. Écriture de soi, individu et liens sociaux (Toulouse: 2010) 9-11. As Nicole Lemaitre asserts, the 'self' may, however, be found in sources other than those classified as 'écrits du for privé', that is, documents not suspected of involving any level of self-disclosure, see Lemaitre N., "Le monde multiforme des écrits de soi: une histoire de voilé-dévoilé", in Mouysset - Ruggiu - Bardet (eds.), Car c'est moy que je peins $15^{-20 .}$

11 Jacques Presser cited and translated in Maschuc M. - Dekker R. - Baggerman A., "Egodocuments and History: A Short Account of the Longue Durée", The Historian 78 (2016) $11-56$, here 11 . 
revealed by the author himself or even accidentally exposed by the author or a third person. ${ }^{12}$ This broad and controversial ${ }^{13}$ definition nonetheless allows us to include in our analyses documents like plaintes en grossesse that testify to a certain self-disclosure and that were otherwise not studied as such by historians. The example of Otto van Eck's diary highlights the importance of Presser's pioneering work. ${ }^{14}$ Rudolf Dekker and Arianne Baggerman have shown that Otto wrote his diary at his parents' request and that it is not the result of the child's personal will: the writing of the diary was therefore a three-way process between Otto and his parents. This document must therefore be seen as an egodocument since the self-disclosure is made by Otto himself, but also by his parents who dictate the writing and the writing environment. ${ }^{15} \mathrm{My}$ aim is not to extend the epistemological boundaries of a concept to the point where it loses all meaning and utility. Rather, I argue that these judicial sources can be read through the eyes of historians of egodocuments to open a new window on the history of the couple and sexuality in the eighteenth century. Research into this mode of self-writing has developed ways to identify self-disclosure in ordinary writing, shedding light on, e.g., the history of sexual intimacy and private life in early modern France. ${ }^{16}$ In line with this research tradition, I find that the plaintes en grossesse offer valuable information: these official documents can be analysed with an eye to an unveiling of the private and intimate behaviours of unmarried couples.

12 Presser, "Egodocuments and History" 11.

13 For a review of the important debate on the notion of egodocument, see Greyerz, "Egodocuments. The Last Word?" 263-272.

14 Dekker R. - Baggerman A., "Sensibilité et éducation d'un enfant à l'époque batave. Le journal intime d'Otto van Eck (1791-1796)", Annales historiques de la Révolution française 326 (2001) 129-139.

15 Dekker R. - Baggerman A., "Sensibilité et éducation" 130-131.

16 Mouysset S., "Quand 'Je' est une femme: les spécificités d'une écriture ordinaire”, in Mouysset - Ruggiu - Bardet (eds.), Car c'est moy que je peins 185-201; Dekker R., "Sexuality, Elites, and Court Life in the Late Seventeenth Century: The Diaries of Constantijn Huygens, Jr.", Eighteenth-Century Life 23.3 (1999) 94-109. Several studies on the history of sexualities in early modern Europe are based on the analysis of egodocuments, which demonstrates the importance of these sources. See Stone L., The Family, Sex and Marriage in England, 1500-1800 (Cambridge: 1977); Roodenburg H., "The Autobiography of Isabella de Moerloose: Sex, Childrearing and Popular Belief in Seventeenth-Century Holland", Journal of Social History 18 (1985) 517-539; Steinberg S., "Quand le silence se fait: brides de paroles de femme sur la sexualité au XVII e siècle”, Clio. Femmes, genre histoire $3^{1}$ (2010) 79-109; Laflamme M., "Un viol dénoncé dans une déclaration de grossesse à Toulouse en 1742", Clio. Femmes, genre histoire $5^{2}$ (2020) 207-220. For a strong methodological essay, see Guzzi-Heeb S., "Egodocuments, biographie et microhistoire en perspective. Une histoire d'amour ?", Études de Lettres 1-2 (2016) 269-304. 
The following demonstration is based on the study of the plaintes en grossesse deposited at the municipal Justice of Toulouse during the eighteenth century. These documents do not reveal indisputable facts or a perfectly unveiled intimacy; they are, by their very nature, subjective sources that require interpretation, nuance, and comparison. Moreover, the complaints were produced in the context of court proceedings and the biases that the legal process imposed upon the discourse on sexual intimacy. As Danièle Tosato-Rigo asserts, 'Personal writing, always singular testimonies, calls for the primacy of interpretation, ${ }^{17}$ and the plaintes en grossesse are no exception. Jeanne Ligonès does not objectively recount her relationship with Couly, but offers a reconstructed and oriented discourse on their relationship. I will seek out traces of sexual intimacy in such testimonies that do not reveal facts of 'how it actually was' ('wie es eigentlich gewesen'), but offer a narrative that is nonetheless telling and important.

\section{Premarital Sexuality in Early Modern France}

Despite secular and religious prohibitions, premarital sexual activity was common in early modern France. Such intimate relations were part of the social rituals of courtship, which preceded marriage. Despite the formal prohibition in French positive law, supported in jurisprudence and canon law, premarital sex was rarely prosecuted. Such relationships were tolerated and not criminalised as long as the lovers remained within the social standards imposed by their immediate neighbourhood and surrounding community. ${ }^{18}$ Indeed, these behaviours were intimate, but also, to some extent, known by the community. Sexual intimacy, then, was considered suspicious and even dangerous. As a consequence, premarital relationships were rarely secret but required discretion. Sexuality was placed under the burden of a double imperative: it had to be discreet and revealed, known but not said, intimate but not secret. Thus, the privilege to have sexual privacy seems to be eclipsed in eighteenthcentury France. While premarital couples could have some sexual intimacy outside the gaze of the community, their relationship could not be kept secret if the couple expected to get married. Jeanne-Marie Farny could not be clearer when she stated that her parents 'ne souffroient ses assiduités qu'en raison de

\footnotetext{
17 Tosato-Rigo, "Introduction" 9.

18 Regina C., Dire et mettre en scène la violence à Marseille au XVIII siècle (Paris: 2017) 118.
} 
l'accomplissement d'un tres prochain mariage' ('suffered her eagerness only because of the completion of a forthcoming marriage'). ${ }^{19}$

The jurisconsult Joseph-Nicolas Guyot (1728-1816) is probably the one who gave the clearest explanation of this fundamental distinction between the theoretical condemnation of premarital sexuality and the relative tolerance of the judicial authorities:

Si la fille s'est abandonnée volontairement à son corrupteur, et que son commerce ait été suivi de grossesse, on ne prononce contre l'auteur de la grossesse qu'une condamnation de dommages et intérêts, qui sont plus ou moins considérables, suivant la qualité et la fortune des parties. [...] on le condamne encore à une somme pour les frais de couche. ${ }^{20}$

If the girl, of her own volition, has surrendered herself to her corrupter, and if her actions have led to pregnancy, the father is only sentenced to pay damages that, depending on the status and wealth of the parties, can be more or less significant [...] furthermore, he is sentenced to pay a sum for the costs of childbirth.

On the level of jurisprudence, judges were not required to convict premarital sexual behaviour if the relationship was consensual and recognised by the community and if it did not lead to an illegitimate pregnancy. Accordingly, in 1770, the capitouls of Toulouse severely condemned a man who was trying to flee the city and his pregnant lover. The magistrates, however, annulled the sentence after the announcement of the couple's engagement, which, de facto, made the defendant the legitimate father of the unborn child. ${ }^{21}$ Legal action was no longer necessary because the child as well as the couple was considered legitimate, thanks to the legally contracted marriage..$^{22}$ In private and public life, unlike in law, premarital sexuality could be tolerated as long as a marriage

$19 \quad$ AMT, FF $824 / 3$ liasse 46.

20 Guyot J.-N., "Fornication", in Guyot J.-N., Répertoire universel et raisonné de jurisprudence civile, criminelle, canonique et bénéficiale, vol. 7 (Paris, chez Visse: 1784) 510.

$21 \quad$ AMT, FF814/6 liasse 152.

22 On this question, see, e.g., Perrier S., "Enfant à naître, conçu, posthume: la filiation entre droit et biologie (France XVII ${ }^{\mathrm{e}}-\mathrm{XVIII}{ }^{\mathrm{e}}$ siècles)", Annales de démographie historique 137 (2019) 75-10o and Steinberg S., "Le droit, les sentiments familiaux et les conceptions de la filiation: à propos d'une affaire de possession d'état au début du XVII e siècle", Annales de démographie historique 118 (2009) 123-142. 
was upcoming or conceivable. ${ }^{23}$ In her plainte en grossesse, Jeanne St-Martin thus states that her parents consented to her illicit sexual activities:

Castel rendoit journellement ses assiduités au vû et sçu de ses père et mère dans leur maison l'assurant de meme qu'a ses parens qu'il vouloit l'épouser et se ne fut que sur ses promesses que ses père et mère souffrirent les assiduités dudit Castel. ${ }^{24}$

In their house, Castel made his daily courtships in plain sight of her father and mother, assuring her as well as her parents that he wanted to marry her, and her father and mother only suffered Castel's constant presence because of his promises.

Indeed, the deposition of a certain Marie Martin is even more revealing of how parental consent allowed a certain sexual intimacy for an unmarried couple:

sous prétexte d'un mariage prochain en le proposans comme tel au père et à la mère de la suppliante $[. .$.$] la mère d'icelle le prit par la main et le$ conduisit dans la chambre de la fille ou elle les laissa seuls

under the pretext of an upcoming marriage, and as he [the former lover] proposed [it] to the father and mother of the supplicant [...] her mother took him by the hand and led him to the girl's room, where she left them alone. ${ }^{25}$

However, the courts harshly condemned men who used written promises of marriage to convince complainants to transgress sexual prohibitions. For example, Jean Moignard was sentenced to pay 1200 livres to the pregnant plaintiff because he abandoned her after having signed, a promise of marriage. ${ }^{26}$

23 Regina C., "Voisinage, violence et féminité: contrôle et régulation des mœurs au siècle des Lumières à Marseille", in Rainhorn J. - Terrier D. (eds.), Étranges voisins. Altérité et relation de proximité dans la ville depuis le XVIII ${ }^{e}$ siècle (Rennes: 2010) 212-235.

24 АMT, FF814/3 liasse 65.

25 АМт, FF829/7 liasse 136.

26 The notarial document was filed in evidence at the request of the magistrates, cf. АMT, FF 776/2 liasse 42 . 
Unmarried pregnant women were not under a legal obligation to declare their pregnancy to a legal authority. ${ }^{27}$ The Royal Edict of 1556 imposed a presumption of infanticide for unmarried women who concealed their pregnancy and whose child died before baptism and without a Christian burial. The declaration of pregnancy was therefore a precaution for women who wanted to avoid the severity of the law. Not all of them felt concerned by the edict. Those who could either take advantage of it in court or protect themselves in case of a difficult pregnancy used it. ${ }^{28}$ The distinction between déclaration de grossesse (declaration of pregnancy) and plainte en grossesse is essential here: the complaint, unlike the declaration, imposed a criminal proceeding. As legal documents, the plaintes en grossesse testify both to the precarious economic situation of the complainants and to the juridical process that these women perceived as a possible remedy: they describe a level of female agency. Matthew Gerber's research on illegitimacy in early modern France has clearly demonstrated the considerable impact of illicit sexual behaviour on the daily life of Ancien Régime families. ${ }^{29}$ Thus, the plainte en grossesse can be viewed as a last resort for many women and their families. ${ }^{30}$ In order to obtain a favourable judgement, public disclosure of sexual intimacy was required, and although most resorted to the courts deliberately, their complaints can hardly be characterised as voluntary.

Pregnancy was irrefutable proof of illicit behaviour: communities and justice officials could infer from physical bodies what had taken place in private. However, it was difficult for these women to have their lovers convicted: the evidence usually remained circumstantial and was based on the testimonies. The plaintiff, first, had an obligation to prove her relationship with the accused and the sincerity of that relationship. The latter required a detail account of emotional states and sexual behaviours. Women described - or were legally requested to describe - the history of their sexual relations with the alleged perpetrator of their pregnancy. Such descriptions span from the

27 For a study on the form and function of the déclarations de grossesse, see Phan M.-C., "Les déclarations de grossesse en France (XVIe-XVIII siècles): essai institutionnel", Revue d'histoire moderne et contemporaine 22.1 (1975) 61-88. For a discussion of the historiographical debates concerning this edict, see Hardwick, Sex in an Old Regime City $25^{-35}$.

28 Phan, Les amours illégitimes 6.

29 Gerber M., Bastards: Politics, Family, and Law in Early Modern France (New York: 2012).

$30 \quad$ False plaintes en grossesse are statistically marginal in my corpus: I have identified only one case in which the capitouls convicted the complainant of a false charge - the surgeons convened by the court said that she was not pregnant when she claimed to be three months pregnant, see AMT, FF799/8 liasse 235 . 
first meeting to the final abandonment. Women had to prove that they were actually seduced: pregnancies had to be the result of something more than a fortuitous or accidental relationship. ${ }^{31}$ This might explain why the majority of abandoned women insisted that they had only consented to intercourse after a long, continuous courtship. This outstretched period seems almost a rhetorical trope in the plaintes en grossesse.$^{32}$ Many women also emphasised the location of their sexual relations. In her complaint, Anne Duparan specified that she had been seduced near the family fireplace in the presence of her mother. ${ }^{33} \mathrm{~A}$ sexual relationship in the home could be used to prove that the relationship was serious and permitted by her parents as a step towards marriage.

From the second half of the eighteenth century, Toulouse's plaintes en grossesse are particularly detailed and statistically more abundant in the archives. For my dissertation, I am working with a corpus of 830 plaintes en grossesse from this period. ${ }^{34}$ Below, the graph represents the distribution by years of pregnancy complaints in Toulouse:

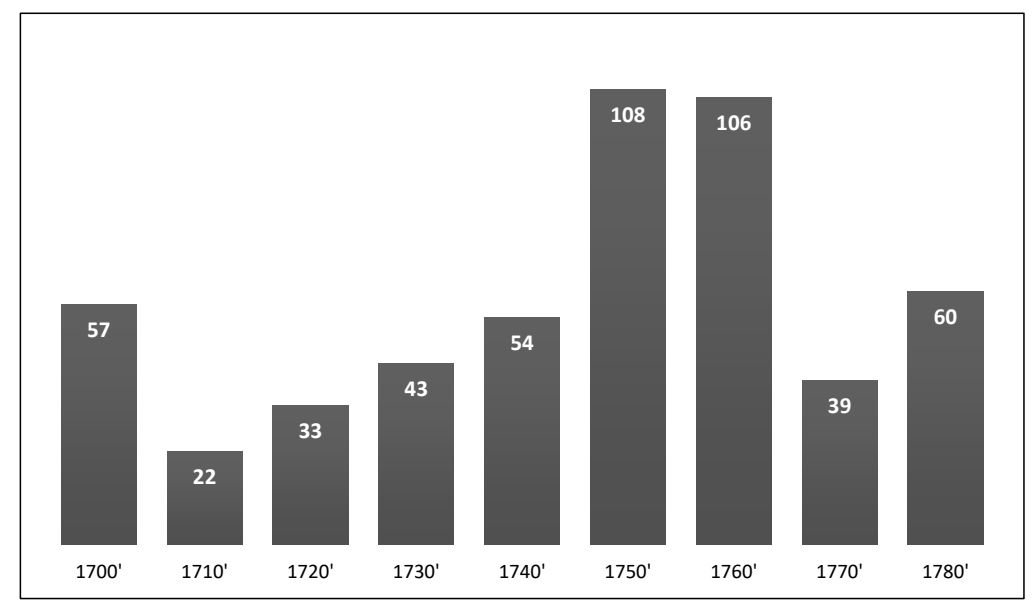

FIGURE 9.1 The number of complaints received by decade

$31 \quad$ Guyot, "Fornication" 513.

32 On average, the complainants state that they resisted between four to six months before accepting their suitor's proposals. Others indicate that the period was even longer, emphasising that the accused put much pressure upon the plaintiff. For example, one complaint asserts that sexual intercourse only took place after a courtship of more than one year, cf. AMT, FF786/2 liasse 30. Another states that the courtship lasted two years before pregnancy, cf. AMT, FF $776 / 1$ liasse 35 .

33 АMт, FF766/2 liasse 81.

34 The corpus was established by sampling all years ending in o, 2, 5, and 7 . The year 1771 was preferred to the year 1770 due to the quality of the preservation of the documents. I include in this corpus the year 179o, the last year for which the plainte en grossesse is mandatory in Toulouse. My study also includes a sub-corpus of about 30 complaints from the seventeenth century. 
We notice a significant increase in the number of complaints from $175^{\circ}$ onwards and a slow decrease around 1765 . The increase can be explained by the monarchical State's imposition of numerous reminders of Henry II's edict. Throughout the eighteenth century, the French monarchy demanded that this edict be read several times in church during services, and local justices also imposed it on their litigants. If other institutions such as the Church and the seigniorial courts were able to register pregnancies, Toulouse's municipal justice system was certainly the preferred institution for lodging complaints. In accordance with the Edict of 1556 , the Church did not intervene in investigations that were conducted by secular authorities. ${ }^{35}$ On this basis, the statistical increase can be explained, above all, by the sheer efficiency of Toulouse's municipal justice, which sought to assert its primacy over the management of everyday urban life. ${ }^{36}$ The municipal courts of justice are therefore privileged witnesses to the private and intimate life.

Following Nicole Lemaitre's assessment, egodocuments underline the porous border between the private and the public sphere, and the plaintes en grossesse are no exception to this rule. ${ }^{37}$ As an injured woman presented her sexual activities to the Toulousian court, she testified to both her and her former lover's intimacy. A plainte en grossesse inevitably imposed an incursion of what we could consider the private space of both plaintiffs and defendants: a public authority investigates and, in some sense, intrudes upon the intimate lives of these couples. Magistrates could also question the accused if he had not fled the scene as was often the case. ${ }^{38}$ As the example of the caffetier cited in the introduction shows, witnesses were asked, under oath, to recount intimate details about unmarried couples. ${ }^{39}$ Accordingly, these documents are precious testimonies to the transgression of the boundaries between private and public: they offer a window into the intimate spaces of unmarried couples. ${ }^{40}$ The

35 Phan, Les amours illégitimes $5^{-8}$.

36 However, the uncertainties of conservation cannot be overlooked when explaining this statistical observation, Faure C., La justice criminelle des capitouls de Toulouse (1566-1789) (Toulouse: 2018) 384-385.

37 Lemaitre, "Le monde multiforme" 19.

38 In an attempt to escape their parental obligations and the public spectacle of a trial, many defendants left Toulouse after the announcement of their lovers' pregnancy. This explains why, in several complaints, the interrogation of the accused is absent. In other cases, the interrogation takes place several months or even years after the complaint has been filed because the accused has returned to the city or has been arrested elsewhere.

39 AMT, FF 812/4 liasse 95.

40 They also offer a window into the sexuality of others since, as Rudolf Dekker points out, egodocuments discuss more deliberately of the sexuality observed than the author's own sexuality. Dekker, "Sexuality, Elites, and Court Life" 95-96. 
premarital sexual lives of 'ordinary people' were generally known to the communities in which these people lived. They were subject to a kind of tacit public knowledge. This aspect of early modern urban life is difficult to ascertain. The plaintes en grossesse highlight this precise tension, however. While sexuality was perceived as private and intimate, testimonies heard in court show that premarital sexual behaviours were generally known within communities. With legal proceedings, sexual behaviours that were 'known, but not said' became 'known and said' and then recorded. Sexual behaviours considered private but known by and thereby accepted within the community were transposed to the legal system, where tacit knowledge was no longer enough: the complainants transferred intimate sexual behaviours from the private domain to the public realm of justice. Plaintes en grossesse allow us to acknowledge precisely this permeable border between private and public, between secrecy and knowledge, which characterises early modern societies.

\section{The Fragile Balance of Ordinary Life}

In early modern France, the intimate sexual lives of men and women largely escaped the eye of justice. In turn, this intimacy is hardly accessible to historians unless they approach it from the perspective of its repression. Toulouse's plaintes en grossesse do not correspond to Madeleine Foisil's definition of Écrits du for privé, since they are documents produced by institutions and not by the actors themselves. Nevertheless, these judicial sources allow us to enter into the sexual and emotional intimacy of illegitimate couples in eighteenth-century France. The use of these sources is all the more interesting because women's writing, and even more so writing on sexuality, is very rare for the eighteenth century. ${ }^{41}$ Indeed, the plaintes en grossesse grant us some access to the intimate lives of women. These documents testify to the ordinary lives of women. Of course, as Gwénael Murphy emphasises, 'deciphering the feelings, the sentiments, the reception of violence by victims, their executioners and the witnesses of these acts through judicial archives remains delicate because of the normative prism imposed by the documents and their editors'.42 Furthermore, the complaints mirror the administrative standards of

41 Mouysset, "Quand 'Je' est une femme" 191; Greyerz K., "Écriture de soi et lecture religieuse chez les protestants du monde germanophone en perspective confessionnelle", Études de Lettres 1-2 (2016) 39-62.

42 Murphy G., "Justice, sociétés et violences conjugales aux XVII ${ }^{\mathrm{e}}$ et XVIII ${ }^{\mathrm{e}}$ siècles: les seuils de tolérance", in Follain A. (ed.), Sources. Arts, civilisation et histoire de l'Europe 14-15 (2019) 119 . 
the period: the clerk's transcription imposes what we might call a reading of the sexuality of the complainants. However, since the complaint was intended to convince the magistrates, these complainants described their sexual and emotional intimacy in great detail that, later, were to be refuted or confirmed by witnesses summoned by the court. ${ }^{43}$ Despite the obvious biases imposed by the judicial process and the intermediation of translators and scribes, ${ }^{44}$ the accounts speak to actual events or, better, to the personal experience of certain events. Indeed, the complaints were always read back to their depositor and had to be approved by her. ${ }^{45}$

The available sources also reflect a conflict or a rupture: the study of harmonious couples and their sexuality remain difficult, if not impossible - it is in its repression and regulation that sexuality fosters a discourse and leaves its trace. In line with Christophe Regina, the plaintes en grossesse can be considered testimonies of troubled ordinary life, which take the form of stories intended for the agents of justice. ${ }^{46}$ These sources are not first-hand accounts of sexuality, and historians, as always, must be aware of their biases. Still, they grant access to social narratives of intimate behaviours: representations of emotional states, rarely accessible, are found in these pages. ${ }^{47}$

A plainte en grossesse starts where things end - at the break-up. Subsequently, the plaintiff accuses her lover of not honouring a promise of marriage - a promise that had facilitated their premarital sexual activities and of his unwillingness to respect parental obligations. This schema enables us to establish an itinerary of the sexual intimacy: the initial period of tolerated sexual intimacy is followed by the break-up that, then, effects the plainte

43 Christophe Regina provides methodological tools for analysing these oral testimonies translated and transcribed by a clerk, and he demonstrates very convincingly that these sources can, with all the necessary nuances, be considered direct testimony. See C. Regina, Dire et mettre en scène.

44 It should be noted that the complainants most likely speak occitan, the vernacular language of eighteenth-century Toulouse. These sources are therefore transcripts of an oral complaint made in occitan and then translated into French.

45 To the plaintes en grossesse as stories told from the inside, where actors of the love drama express themselves or, at the very least, the seduced girl does, see Phan, Les amours illégitimes 3 .

46 Regina C., Genre, mœurs et justice: les Marseillaises et la violence au XVIII ${ }^{e}$ siècle (Aix-en-Provence: 2015) 23.

47 Indeed, the historical research into women's sensitivities cannot be limited to sources about women, but it must turn to sources from women, see Vickery A., "'S'il vous plait, brûler cela afin qu'aucun œil mortel ne puisse le voir': les secrets des sources féminines", in Ruggiu F.-J. - Bardet J.-P. (eds.), Au plus près du secret des coeurs? Nouvelles lectures historiographiques des écrits du for privé en Europe du XVI e au XVIII ${ }^{e}$ siècle (Paris: 2005) 43-62, here 46. 
en grossesse. The initial period of toleration is oriented towards the future: the couple, their families, and the community tolerate sexual behaviours, interpreting them as signs of marriage. The rupture turns this interpretation on its head: it transforms behaviours from 'normal' to 'transgressive.' Finally, the plaintes en grossesse is a way for women to handle this transgression of social norms - to reinterprete what happened to her and her family.

Thus, the plaintes en grossesse document the evolution of the amorous sentimental relationship from first encounters to break-ups. In her complaint, Marthe Boulbe states that her former lover

[...] rechercha de faire connoissance avec la plaignante et fit si bien qu'il s'introduisit auprès d'elle et commança d'abort a se débiter comme un homme qui est tout a fait amoureux. La plaignante regardoit cette Grande passion avec mépris mais la constance dudit Alexis obligea la plaignante de le regarder avec complaisance. ${ }^{48}$

sought to get to know the plaintiff and did this so well that he introduced himself to her and immediately started acting like a man completely in love. This great passion the plaintiff viewed with contempt, but the persistence of Alexis [the defendant] obliged the plaintiff to look at him with complacency.

In another case, the complainant asserts that her seduction was long, constant, and non-coercive:

le susdit s'estant rendeu amoureux d'elle il luy communiquoit ses tendres sentiments qui augmentoient disoit tous les jours et elle qui se plaint n'ayant pu doutter de la sincérité dudit St-Martin qui la suivoit dans tous les endroits de la maison les plus reculés feut enfin forcée de consentir a ses désirs. ${ }^{49}$

after the aforementioned [lover] had fallen in love with her, he communicated his tender feelings that he said increased daily, and, finally, she, the plaintiff, having found no reason to doubt St-Martin [the lover] who followed her into the remotest areas of the house, was forced to consent to his desires.

48 AMT FF 759/2 liasse 57.

49 Амт, FF784/6 liasse 155. 
Descriptions like these are by no means neutral: the plaintes en grossesse were filed for compensation. Since these sources originate from a dispute, the complainant's narrative usually begins with a description of a harmonious relationship and ends with a dramatic and immoral experience:

luy temoignant au commancement de leurs connoissances une consideration respectueuse qui se changea bientôt en amour meme indiscret ledit Mestre l'ambrassant dans tous les androits de la maison ou il la trouvoit lui faisant meme des attouchements illicites dont elle ne pouvoit se deffandre. ${ }^{50}$

having at the beginning of their acquaintance shown a respectful acknowledgement of her, which soon turned into love, Mestre, indiscreetly, would embrace her in all the corners of the house where he found her, making even illicit gropings from which she could not defend herself.

Some women tried to convince the authorities by emphasising how their abandonment inflicted a grave loss upon their own person, their families, and their community. In a deposition made in 1773 , a complainant's midwife asserted that the defendant: 'Ledit Roland luy ayant assisté luy meme a ses couches la tenant meme sur ses jenouls pendant qu'elle accoucha' ('the aforementioned Roland [the lover] assisted her childbirth holding her on his knee while she gave birth'). ${ }^{51}$ This witness brings us into the intimacy of childbirth and documents the couple's relationship. The example of the caffetier is again illuminating: he transgressed the threshold of the private bedroom and retrieved information from its interior about which he was compelled to describe details, that is, his experience became evidence to support the intimacy of a couple that a judicial authority was in the process of authenticating. In the same proceedings, a 5o-year-old widow testified that the lover 'couchoit la plus part du tems' ('slept most of the time') in the complainant's room. This witness also confirmed that the couple was recognised as legitimate in the neighbourhood. ${ }^{52}$ Furthermore, a man testified in court that he noticed 'qu'ils étoient l'un et l'autre fort rouges ce qui lui fit soubsonner qu'ils venoient de se divertir' ('that both of them [the illegitimate couple] were very red [in the face], which made him suspect that they had just entertained themselves') ${ }^{53}$ More than implying the act of

\footnotetext{
$5^{\circ} \quad$ AMT, FF 751/1 liasse 5 .

51 AMT, FF 774/5 liasse 15 O.

52 АMT, $\mathrm{FF} 812 / 4$ liasse 95 .

53 AMT, FF 804/5 liasse 147.
} 
intercourse, the witness had not actually seen the act, but it seems from his statement that he might as well have: he was able to describe the physical state of the lovers who had just had sex.

The very act of filing a complaint was likely to cause the publication of the complainant's sexual intimacy. Pierre Barthès, a famous Toulouse memoirist, asserts that nothing is secret at the court of the capitouls and that it was public knowledge that the intimacy revealed to the magistrates risked being revealed in the streets of Toulouse. ${ }^{54}$ Nicole Castan claims that court procedures were genuine entertainments in eighteenth-century Toulouse. ${ }^{55}$ By choosing to file a complaint, the complainants had to accept a double unveiling of their sexual intimacy: one in the legal proceedings and the other in the streets of Toulouse. What was known by one part of the community could now be known by all.

\section{$4 \quad$ Conclusion}

It is the suspension of ordinary life - the illegitimate pregnancy followed by abandonment - that spurred on attempts to restore some level of normality. The plaintes en grossesse are such attempts, and, despite their normative nature, they allow us to enter into the privacy of the bedroom, sit by the fireplace, and walk the streets where lovers used to go for promenades. Indeed, the judicial procedure required that facts, otherwise silenced, had to be pronounced, taken on record, and, years after, be available for scrutiny by historians. For too long, the sexual intimacy of illegitimate eighteenth-century French couples has not been studied. Through the methodological and conceptual approaches developed by the historians of egodocuments, the study of plaintes en grossesse gains access to the restricted and private spaces that surrounded sexuality in early modern France.

While the sexual act is intimate and, as such, private, judicial sources suggest that sexual privacy was difficult to achieve for illegitimate couples. This is not a simple contrast between private and public but something much more complex and interesting: the community's tacit knowledge of a premarital relationship situates sexuality at the intersection of public and private, while the legal proceedings, where the State manifests itself in matters of everyday

54 Les Heures perdues de Pierre Barthès maître répétiteur en Toulouse, ou recueil des choses dignes d'être transmises à la posterité, arrivées en cette ville, ou prés d'icy, Bibliothèque municipale de Toulouse, ms. 699-706. The memoirs of Pierre Barthès can be consulted online on the website of the Bibliothèque municipale de Toulouse (https://rosalis.bibliotheque .toulouse.fr/).

55 Castan N., Justice et répression en Languedoc à l'époque des Lumières (Paris: 1980) 142-143. 
life, required a more clear-cut knowledge about what had 'actually' taken place in the private domain. On the one hand, the communal knowledge about the couples' behaviours was already intrusive: it monitored couples and their intimate behaviours. On the other hand, what is known by the family and the community is not necessarily known by the general public. The legal authorities, however, required that the couple's seal of intimacy be broken: the capitouls ordered the complainant to tell every detail of her sex life with her runaway lover, while the latter, when arrested, was required to do the same. More importantly, the woman made the decision to open her bedroom and invite in the judicial gaze. The plainte en grossesse was not, at least theoretically, imposed: in her dire straits, the individual resorted to this social practice and legal procedure, which entailed disclosing sensitive matters about her person and sexual activities. Thus, these documents testify to some level of female agency for women, when their lovers went back on promises of marriage and thereby called into question the sincerity of the relationship. ${ }^{56} \mathrm{~A}$ form of tacit exchange thus took place: the plaintiff agreed to provide to the justice the details of her intimate sexual life in exchange for a possible conviction of her former partner. The discourses on the sexual intimacy of these premarital couples, e.g. the different zones of privacy, are thus compiled in a single legal procedure that is now accessible to historians. As Claire Judde de Larivière suggested, the study of these documents demonstrates that an alternative history of the self and the intimate can be studied through the analysis of certain documents produced within or requested by institutions. ${ }^{57}$ The intimacy of the couple's bedroom was, after all, opened to the curiosity and surveillance of the community.

56 The plaintes en grossesse also testify to sexual violence against women - such acts of physical, emotional, and verbal violence were a scourge in eighteenth-century Toulouse. Fabrice Vigier has shown how, during the Ancien Régime, a crime was qualified as rape under three conditions: the victim had to be female; physical force had to have been used against her; and finally, it was essential that the victim resisted her attacker until the end of the act, see Vigier, "À propos de quelques procès pour violences sexuelles dans le Poitou du XVIII ${ }^{\mathrm{e}}$ siècle" 201. It goes without saying that this made it difficult for a victim to have an attack recognised as rape. Therefore, many victims used the procedure of the plainte en grossesse to indirectly denounce sexual violence and thereby overcome the near-impossibility for eighteenth-century women to have their abusers convicted. On this use of plaintes en grossesse, I refer to my article "Un viol dénoncé dans une déclaration de grossesse à Toulouse en 1742 ".

57 De Larivière C.J., "Les relazioni des ambassadeurs vénitiens et l'expression du for privé dans les documents publics (XVI e siècle)", in Mouysset - Ruggiu - Bardet (eds.), Car c'est moy que je peins $205^{-220}$, here 205. 


\section{Bibliography}

\section{Manuscripts}

Les Heures perdues de Pierre Barthès maître répétiteur en Toulouse, ou recueil des choses dignes d'être transmises à la posterité, arrivées en cette ville, ou prés d'icy, Bibliothèque municipale de Toulouse, ms. 699-706.

\section{Toulouse Municipal Archives (AMT)}

AMT, $\mathrm{FF}_{751} / 1$ liasse 5

AMT, $\mathrm{FF}_{759} / 2$ liasse 57

AMT, $\mathrm{FF}_{7} 66 / 2$ liasse 81

AMT, $\mathrm{FF}_{774} / 5$ liasse 150

AMT, $\mathrm{FF}_{776} / 1$ liasse 35

Амт, $\mathrm{FF}_{776} / 2$ liasse 42

AMT, $\mathrm{FF}_{7} 86 / 2$ liasse 30

АM, $\mathrm{FF}_{786} / 4$ liasse 81

AMT, $\mathrm{FF}_{7} 84 / 6$ liasse 155

Амт, $\mathrm{FF}_{799} / 8$ liasse 235

АMT, FF804/5 liasse 147

AMT, FF812/4 liasse 95

AMT, FF814/3 liasse 65

АМт, FF814/6 liasse $15^{2}$

AMT, FF824/3 liasse 46

AMT, FF829/7 liasse 136

\section{Printed Books}

Arnoul É. - Renard-Foultier R. - Ruggiu F.-J., "Les écrits du for privé en France de la fin du Moyen Âge à 1914: bilan d'une enquête scientifique en cours. Résultats de 2008-2010", in Henryot F. (ed.), L'historien face au manuscrit. Du parchemin à la bibliothèque numérique (Louvain-la-Neuve: 2012) 167-188.

Castan N., Justice et répression en Languedoc à l'époque des Lumières (Paris: 1980).

Certeau M. de, L'invention du quotidien (Paris: 1990 [1980]).

Dekker R., "Sexuality, Elites, and Court Life in the Late Seventeenth Century: The Diaries of Constantijn Huygens, Jr.", Eighteenth-Century Life 23.3 (1999) 94-109.

Dekker R. - Baggerman A., "Sensibilité et éducation d'un enfant à l'époque batave. Le journal intime d'Otto van Eck (1791-1796)", Annales historiques de la Révolution française 326 (2001) 129-139.

Faure C., La justice criminelle des capitouls de Toulouse (1566-1789) (Toulouse: 2018).

Foisil M., "L'écriture du for privé", in Aries P. - Duby G. - Chartier R. (eds.), Histoire de la vie privée, vol. 3 (Paris: 1985) 319-357. 
Foucault M., Histoire de la sexualité. La volonté de savoir (Paris: 1984).

Gerber M., Bastards: Politics, Family, and Law in Early Modern France (New York: 2012). Guyot J.-N., "Fornication", in Guyot J.-N., Répertoire universel etraisonné de jurisprudence civile, criminelle, canonique et bénéficiale, vol. 7 (Paris, chez Visse: 1784) 510-513.

Guzzi-Heeb S., "Egodocuments, biographie et microhistoire en perspective. Une histoire d'amour ?", Étude de Lettres 1-2 (2016) 269-304.

Grendi E., "Microanalisi e storia sociale”, Quaderni Storici 35 (1977).

Greyerz K., "Egodocuments. The Last Word?", German History 28 (2010) 263-272.

Greyerz K., "Écriture de soi et lecture religieuse chez les protestants du monde germanophone en perspective confessionnelle", Étude de Lettres 1-2 (2016) 39-62.

Hanafi N., Le frisson et le baume. Expériences féminines du corps au Siècle des lumières (Rennes: 2017).

Hardwick J., Sex in an Old Regime City: Young Workers and Intimacy in France, 1660-1789 (Oxford: 2020).

Holloway S., The Game of Love in Georgian England: Courtship, Emotions, and Material Culture (Oxford: 2019).

Laflamme M., "Un viol dénoncé dans une déclaration de grossesse à Toulouse en 1742", Clio. Femmes, genre histoire $5^{2}$ (2020) 207-220.

Larivière C.J. de, "Les relazioni des ambassadeurs vénitiens et l'expression du for privé dans les documents publics (XVIe siècle)", in Mouysset S. - Ruggiu F.-J. - Bardet J.-P. (eds.), Car c'est moy que je peins. Écriture de soi, individu et liens sociaux (Toulouse: 2010) 205-220.

Lemaitre N., "Le monde multiforme des écrits de soi: une histoire de voilé-dévoilé", in Mouysset S. - Ruggiu F.-J.- Bardet J.-P. (eds.), Car c'est moy que je peins. Écriture de soi, individu et liens sociaux (Toulouse: 2010) 15-20.

Lipscomb S., The Voices of Nîmes: Women, Sex, and Marriage in Reformation Languedoc (Oxford: 2019).

Maschuc M. - Dekker R. - Baggerman A., "Egodocuments and History: A Short Account of the Longue Durée", The Historian 78 (2016) 11-56.

Mouysset S. - Ruggiu F.-J. - Bardet J.-P. (eds.), Car c'est moy que je peins. Écriture de soi, individu et liens sociaux (Europe, $X V^{e}-X X^{e}$ siècle) (Toulouse: 2010 ).

Mouysset S., "Quand 'Je' est une femme: les spécificités d'une écriture ordinaire”, in Mouysset S. - Ruggiu F.-J. - Bardet J.-P. (eds.), Car c'est moy que je peins. Écriture de soi, individu et liens sociaux (Toulouse: 2010) 185-201.

Perrier S., "Enfant à naître, conçu, posthume: la filiation entre droit et biologie (France XVII ${ }^{\mathrm{e}}-\mathrm{XVIII}{ }^{\mathrm{e}}$ siècles)", Annales de démographie historique 137 (2019) 75-100.

Phan M.-C., "Les déclarations de grossesse en France (XVI ${ }^{\mathrm{e}}-\mathrm{XVIII}$ siècles): essai institutionnel", Revue d'histoire moderne et contemporaine 22.1 (1975) 61-88.

Phan M.-C., Les amours illégitimes. Histoires de séduction en Languedoc (1676-1789) (Paris: 1986). 
Regina C., Dire et mettre en scène la violence à Marseille au XVIII ${ }^{e}$ siècle (Paris: 2017).

Regina C., Genre, mours et justice: les Marseillaises et la violence au XVIII e siècle (Aix-en-Provence: 2015).

Regina C., "Voisinage, violence et féminité: contrôle et régulation des mœurs au siècle des Lumières à Marseille", in Rainhorn J. - Terrier D. (eds.), Étranges voisins. Altérité et relation de proximité dans la ville depuis le XVIII e siècle (Rennes: 2010) 212-235.

Roodenburg H., "The Autobiography of Isabella de Moerloose: Sex, Childrearing and Popular Belief in Seventeenth Century Holland", Journal of Social History 18 (1985) 517-539.

Roussel D., "La description des violences féminines dans les archives criminelles du XVI ${ }^{\mathrm{e}}$ siècle”, Tracés. Revue de Sciences humaines 19 (2010) 65-81.

Ruggiu F.-J. - Bardet J.-P. (eds.), Au plus près du secret des cours? Nouvelles lectures historiographiques des écrits du for privé en Europe du XVI e au XVIII ${ }^{e}$ siècle (Paris: 2005).

Ruggiu F.-J., "Les écrits du for privé: une perspective européenne", in Bardet, J.-P. Arnoul E. - Ruggiu F.-J. (eds.), Les écrits du for privé en Europe du Moyen Age à l'époque contemporaine (Bordeaux: 2010) 9-18.

Steinberg S., "Le droit, les sentiments familiaux et les conceptions de la filiation: à propos d'une affaire de possession d'état au début du XVII ${ }^{\mathrm{e}}$ siècle", Annales de démographie historique 118 (2009) 123-142.

Stone L., The Family, Sex and Marriage in England, 1500-1800 (Cambridge: 1977).

Taillefer M., Vivre à Toulouse sous l'Ancien Régime (Toulouse: 2014).

Tosato-Rigo D. (ed.), Appel à témoins. Écrits personnels et pratiques socioculturelles $\left(X V I^{e}-X X^{e} s\right.$.), Études de lettres (Lausanne: 2016).

Steinberg S., "Quand le silence se fait: brides de paroles de femme sur la sexualité au XVII ${ }^{\mathrm{e}}$ siècle", Clio. Femmes, genre, histoire 31 (2010) 79-109.

Vickery A., "S'il vous plaît, brûler cela afin qu'aucun œil mortel ne puisse le voir': les secrets des sources féminines", in Ruggiu F.-J. - Bardet J.-P. (eds.), Au plus près du secret des cours? Nouvelles lectures historiographiques des écrits du for privé en Europe du XVI e au XVIII ${ }^{e}$ siècle (Paris: 2005) 43-62.

Vigier F., "À propos de quelques procès pour violences sexuelles dans le Poitou du XVIII" siècle", in Chauvaud F. (ed.), Le corps en lambeaux: Violences sexuelles et sexuées faites aux femmes (Rennes: 2016) 201-225. 